\title{
An evaluation of two methods of bacteriocine typing of organisms of the genus Proteus
}

\author{
I. J. AL-JUMAILI \\ From the Department of Microbiology, Royal Victoria Infirmary, Newcastle upon Tyne
}

SYNOPSIS An assessment of two simple methods of typing Proteus isolates using bacteriocines is described. The methods chosen were those of Cradcck-Watson and Al-Jumaili. It has been shown that the use of liquid bacteriocine preparations is more satisfactory than methods involving proteo- $\propto$ cine production in solid media. For example, no non-typable isolates were encountered and a large $\vec{\circ}$ number of strains were demonstrated. This method is therefore proposed for use in a routine $D_{\infty}$ diagnostic laboratory.

Previously described bacteriocine typing systems for use with Proteus isolates (Cradock-Watson, 1965) have proved unsatisfactory. Indeed, of 252 isolates tested by this method, only 139 described as Proteus mirabilis and one described as Proteus vulgaris were shown to produce bacteriocines $(55.5 \%)$. However, a higher proportion $(75 \%)$ of isolates tested by the Central Public Health Laboratory (Colindale) (CPHL) were found to be typable (Pitt, personal communication). A typing scheme based on the bacteriocine sensitivities of unknown isolates to standard proteocine preparations has now been developed and tested (Al-Jumaili, 1975) and the purpose of this work is to compare the epidemiological value of these two previously described systems.

\section{Materials and Methods}

SOURCE OF ISOLATES

Two hundred and four isolates of Proteus were supplied by T. L. Pitt, Cross-infection Reference Laboratory, Colindale. Two hundred of these, which had been identified specifically as $P$. mirabilis, had been originally obtained during an investigation into an outbreak of Proteus infection in a neonatal unit in Boston City Hospital, details of which are described by Burke et al (1970). These included three isolates taken from the same nurse (Nurse A) suspected of causing the outbreak, and strains taken from six infants admitted by that nurse.

The other four were gentamicin resistant isolates sent to the CPHL from the Central Middlesex

Received for publication 15 April 1975.
Hospital. They originated from four patients in the same surgical ward. Two were blood specimens, one음 catheter urine, and the fourth from a wound swab. These had all been identified as $\boldsymbol{P}$. vulgaris.

METHOD OF TYPING

The method of typing was that described Al-Jumaili in which the sensitivities of the unknown isolates to 12 standard proteocine preparations are determined (Al-Jumaili, 1975). All isolates had been $\widetilde{\perp}$ previously investigated using the method of CradockWatson.

\section{Results}

The results of typing the 204 isolates by the method용 of Cradock-Watson are shown in table I. The resultsoof typing the same 204 isolates by the method of Al-Jumaili are shown in table II. Only patterns 1 too 33 were demonstrated, and all the isolates were found to be typable.

A comparison between the Al-Jumaili patterns

\begin{tabular}{lll}
\hline Cradock-Watson Type & Number & Approx. \% \\
\hline 1 & 37 & 18 \\
2 & 17 & $8 \cdot 3$ \\
3 & 12 & $5 \cdot 8$ \\
4 & 22 & $10 \cdot 8$ \\
5 & 11 & $5 \cdot 4$ \\
6 & 17 & $8 \cdot 3$ \\
9 & 20 & $9 \cdot 8$ \\
Non-typable & 46 & 23 \\
Miscellaneous and atypical & 22 & $10 \cdot 8$ \\
\hline
\end{tabular}

Table I Results obtained on typing 204 isolates of Proteus by the Cradock-Watson method 


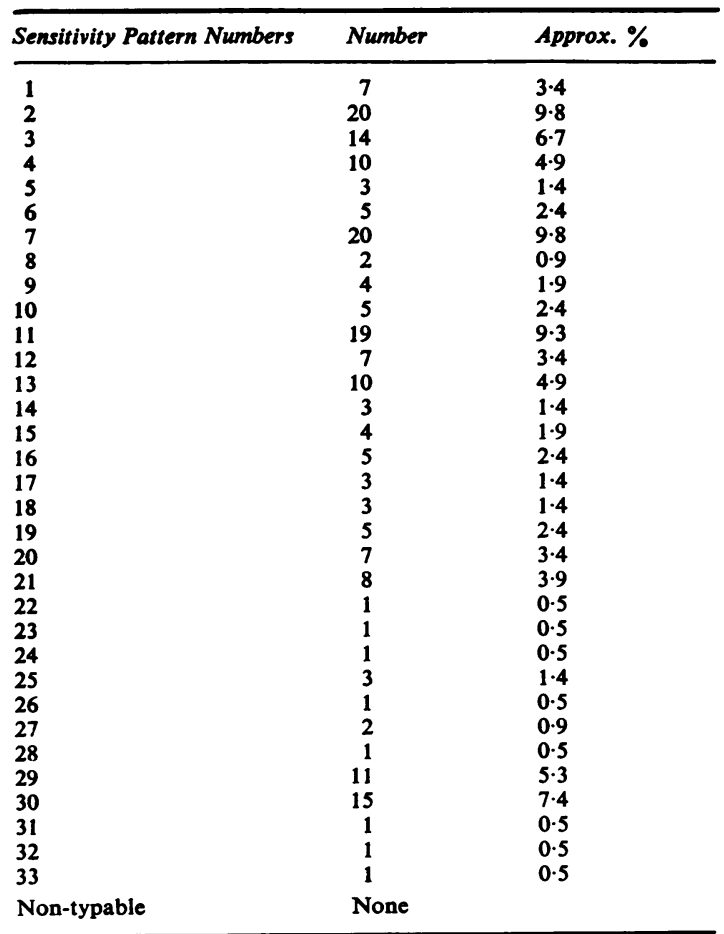

Table II Results obtained on typing 204 isolates of Proteus by the Al-Jumaili method and the Cradock-Watson types is given in table III. The number of isolates with different Al-Jumaili patterns within Cradock-Watson types is illustrated. Table IV shows the number of patterns into which the Al-Jumaili method subdivides each CradockWatson type. Table $\mathrm{V}$ shows the results of the tests on the three isolates taken from nurse $A$ and the strains from the six infants admitted by her. Finally, the typing results of the four gentamicin resistant isolates sent from the surgical ward of the Central Middlesex Hospital are shown in table VI.

A further 33 isolates originally obtained from CPHL were provided by Dr R. H. George, Virology Department, Birmingham University. These had been previously typed by the Cradock-Watson method, by bacteriophage, serologically, by the Dienes phenomenon, and by a resistogram method. These too were typed by the Al-Jumaili method.

The 33 isolates were thus known to comprise 21 serologically distinct types (de Louvois, 1969) and divided into 10 sensitivity patterns using bacteriophage, three isolates being untypable (CPHL, unpublished data). The same 33 isolates had been typed using the Cradock-Watson method on two occasions with identical results, giving nine types with two untypable isolates (George, unpublished results; CPHL, unpublished results). In addition, 26 types had been demonstrated using the Dienes

\begin{tabular}{|c|c|c|c|c|c|c|c|c|c|c|}
\hline \multirow{2}{*}{$\begin{array}{l}\text { Al-Jumaili } \\
\text { Sensitivity } \\
\text { Pattern }\end{array}$} & \multicolumn{7}{|c|}{ Cradock-Watson Types } & \multirow[t]{2}{*}{ Non-typable } & \multirow{2}{*}{$\begin{array}{l}\text { Miscellaneous } \\
\text { and Atypical }\end{array}$} & \multirow[t]{2}{*}{ Total } \\
\hline & 1 & 2 & 3 & 4 & 5 & 6 & 9 & & & \\
\hline 1 & & & & & & & & 2 & 5 & 7 \\
\hline $\begin{array}{l}2 \\
3\end{array}$ & & & & & & & 18 & 2 & & 20 \\
\hline $\begin{array}{l}3 \\
4\end{array}$ & 13 & & & & & & & & 1 & 14 \\
\hline $\begin{array}{l}4 \\
5\end{array}$ & & 1 & 3 & & 6 & & & & & 10 \\
\hline $\begin{array}{l}5 \\
6\end{array}$ & & & 2 & & & & & 1 & & 3 \\
\hline $\begin{array}{l}6 \\
7\end{array}$ & 3 & & & & & & & 2 & & 5 \\
\hline $\begin{array}{l}7 \\
8\end{array}$ & & & & 1 & & & & 14 & 5 & 20 \\
\hline $\begin{array}{l}8 \\
9\end{array}$ & & & & 3 & & & & & 2 & 2 \\
\hline 10 & & & & 3 & 5 & & & 1 & & $\begin{array}{l}4 \\
5\end{array}$ \\
\hline 11 & & & & & & 17 & & & & $\begin{array}{r}5 \\
19\end{array}$ \\
\hline $\begin{array}{l}12 \\
13\end{array}$ & 7 & & & & & 17 & & & 2 & $\begin{array}{r}19 \\
7\end{array}$ \\
\hline $\begin{array}{l}13 \\
14\end{array}$ & 4 & 4 & & & & & & 2 & & 10 \\
\hline $\begin{array}{l}14 \\
15\end{array}$ & 1 & & & & & & & 2 & & 3 \\
\hline $\begin{array}{l}15 \\
16\end{array}$ & 3 & & & & & & & & 1 & 4 \\
\hline $\begin{array}{l}16 \\
17\end{array}$ & 1 & & 2 & & & & & 2 & & 5 \\
\hline $\begin{array}{l}17 \\
18\end{array}$ & & & 2 & & & & & & 1 & 3 \\
\hline $\begin{array}{l}18 \\
19\end{array}$ & 1 & & & & & & 1 & 1 & & 3 \\
\hline $\begin{array}{l}19 \\
20\end{array}$ & & & & 3 & & & & 2 & & 5 \\
\hline $\begin{array}{l}20 \\
21\end{array}$ & 1 & 1 & 1 & & & & & 1 & 3 & 7 \\
\hline $\begin{array}{l}21 \\
22\end{array}$ & & & & & & & & 8 & 1 & 8 \\
\hline 23 & & & & & & & 1 & & 1 & 1 \\
\hline 24 & & & & & & & & 1 & & 1 \\
\hline $\begin{array}{l}25 \\
26\end{array}$ & 3 & & & & & & & & & 3 \\
\hline 26 & & & & & & & & 1 & & 1 \\
\hline $\begin{array}{l}27 \\
28\end{array}$ & & & & & & & & 2 & & 2 \\
\hline $\begin{array}{l}28 \\
29\end{array}$ & & & & & & & & 1 & & 1 \\
\hline $\begin{array}{l}29 \\
30\end{array}$ & & 11 & 1 & & & & & & & 11 \\
\hline $\begin{array}{l}30 \\
31\end{array}$ & & & 1 & 15 & & & & & & 16 \\
\hline $\begin{array}{l}31 \\
32\end{array}$ & & & & & & & & 1 & & 1 \\
\hline $\begin{array}{l}32 \\
33\end{array}$ & & & 1 & & & & & & 1 & 1 \\
\hline Total & 37 & 17 & 12 & 22 & 11 & & & & 22 & 1 \\
\hline & & & & & & 17 & 20 & 46 & 22 & \\
\hline
\end{tabular}




\begin{tabular}{|c|c|c|c|c|c|c|c|c|c|}
\hline & \multicolumn{7}{|c|}{ Cradock-Watson Types } & \multirow[t]{2}{*}{ Non-typable } & \multirow{2}{*}{$\begin{array}{l}\text { Miscellaneous and } \\
\text { Atypical }\end{array}$} \\
\hline & 1 & 2 & 3 & 4 & 5 & 6 & 9 & & \\
\hline $\begin{array}{l}\text { Al-Jumaili } \\
\text { Sensitivity } \\
\text { Pattern } \\
\text { Numbers }\end{array}$ & $\begin{array}{r}3 \\
6 \\
12 \\
13 \\
14 \\
15 \\
16 \\
18 \\
20 \\
25\end{array}$ & $\begin{array}{r}4 \\
13 \\
20 \\
29\end{array}$ & $\begin{array}{r}4 \\
5 \\
16 \\
17 \\
20 \\
30 \\
33\end{array}$ & $\begin{array}{r}7 \\
9 \\
19 \\
30\end{array}$ & $\begin{array}{r}4 \\
10\end{array}$ & 11 & $\begin{array}{r}2 \\
18 \\
23\end{array}$ & $\begin{array}{r}1 \\
2 \\
5 \\
6 \\
7 \\
9 \\
13 \\
14 \\
16 \\
18 \\
19 \\
20 \\
21 \\
24 \\
26 \\
27 \\
28 \\
31 \\
18\end{array}$ & $\begin{array}{r}1 \\
3 \\
7 \\
8 \\
11 \\
15 \\
17 \\
20 \\
22 \\
32\end{array}$ \\
\hline
\end{tabular}

Table IV Al-Jumaili sub-divisions within Cradock-Watson types

\begin{tabular}{|c|c|c|c|c|c|c|c|c|c|c|c|c|c|c|c|c|}
\hline \multirow[t]{2}{*}{ Patient } & \multirow[t]{2}{*}{ Source } & \multirow[t]{2}{*}{ Ward } & \multirow{2}{*}{$\begin{array}{l}\text { Ref. } \\
\text { Lab. } \\
\text { No. }\end{array}$} & \multirow{2}{*}{$\begin{array}{l}\text { Cradock- } \\
\text { Watson } \\
\text { Type }\end{array}$} & \multicolumn{12}{|l|}{$B J$} \\
\hline & & & & & 1 & 2 & 3 & 4 & 5 & 6 & 7 & 8 & 9 & 10 & 11 & 12 \\
\hline Nurse A (1) & Vagina & Mat 1 & 868 & 4 & - & - & - & + & - & + & - & - & - & - & - & - \\
\hline Nurse A (2) & Vagina & Mat 1 & 869 & Non-typable & - & - & - & - & - & $\div$ & - & - & + & - & - & + \\
\hline Nurse A (3) & Hand & Mat 1 & 870 & Non-typable & - & - & - & - & - & + & - & - & + & - & - & + \\
\hline Child 1 & Umbilicus & Mat 1 & 834 & Non-typable & - & - & - & - & - & + & - & - & + & - & - & + \\
\hline Child 2 & Rectum & Mat 1 & 860 & Non-typable & - & - & - & - & - & + & - & - & $\div$ & - & - & - \\
\hline Child 3 & Rectal & Mat 1 & 861 & Non-typable & - & - & - & - & - & + & - & - & $\dot{+}$ & - & - & + \\
\hline Child 4 & Umbilicus & Mat 1 & 838 & Non-typable & - & - & - & - & - & + & - & - & + & - & - & + \\
\hline Child 5 & Umbilicus & Mat 1 & 854 & 4 & - & - & - & + & - & + & - & - & - & - & - & - \\
\hline Child 6 & Rectal & Mat 1 & 856 & 4 & - & - & - & + & - & + & - & - & - & - & - & - \\
\hline
\end{tabular}

Table V Proteocine typing of isolates taken from Nurse $A$ and six infants she admitted, using both methods

\begin{tabular}{|c|c|c|c|c|c|c|c|c|c|c|c|c|c|c|c|}
\hline \multirow[t]{2}{*}{ Patient } & \multirow[t]{2}{*}{ Source } & \multirow{2}{*}{$\begin{array}{l}\text { Ref. Lab. } \\
\text { No. }\end{array}$} & \multirow{2}{*}{$\begin{array}{l}\text { Cradock-Watson } \\
\text { Type }\end{array}$} & \multicolumn{12}{|l|}{$B J$} \\
\hline & & & & 1 & 2 & 3 & 4 & 5 & 6 & 7 & 8 & 9 & 10 & 11 & 12 \\
\hline $\mathbf{G}$ & Blood & 2965 & 2 & - & - & - & + & + & + & - & - & - & - & + & - \\
\hline $\mathbf{B}$ & Blood & 2966 & 2 & - & - & - & + & + & + & - & - & - & - & + & - \\
\hline C & Catheter urine & 2967 & 2 & - & - & - & + & + & + & - & - & - & - & + & - \\
\hline $\mathbf{S}$ & Wound swab & 2968 & 2 & - & - & - & + & + & + & - & - & - & - & + & - \\
\hline
\end{tabular}

Table VI Proteocine typing of four gentamicin resistant strains from the Middlesex Hospital

phenomenon as a marker (Kashbur et al, 1974), and by the resistogram technique the 33 isolates had been shown to consist of 28 different strains (Kashbur et al, 1974). The Al-Jumaili system demonstrated 18 proteocine sensitive patterns with no untypable isolates (table VII).

\section{Discussion}

In the selection of a Proteus typing method for routine use it was felt that bacteriocine typing was the method of choice, as far as reliability, reproduci- $\widetilde{\Omega}$ bility, and consistency are concerned. It is apparent, $N$ moreover, that methods using liquid bacteriocine $\underset{\mathrm{W}}{\mathrm{S}}$ preparations are more successful than those relying $\sigma$ on proteocine preparation in solid media. This is exemplified by the present comparison between the existing Cradock-Watson and Al-Jumaili typing $\stackrel{\oplus}{\rightarrow}$ schemes.

The main advantages of the Al-Jumaili system over the Cradock-Watson method are:

1 the $100 \%$ typability obtained using the 


\begin{tabular}{|c|c|c|c|c|c|c|c|c|c|c|c|c|c|c|c|c|c|c|c|}
\hline \multirow{2}{*}{$\begin{array}{l}\text { Ref. } \\
\text { Lab. } \\
\text { No. }\end{array}$} & \multicolumn{2}{|c|}{ Serology } & \multirow{2}{*}{$\begin{array}{l}\text { CW } \\
\text { Proteocine } \\
\text { Typing }\end{array}$} & \multicolumn{13}{|c|}{$\begin{array}{l}\text { Al-Jumaili Proteocine Typing } \\
\text { Sensitivity Patterns }\end{array}$} & \multirow[t]{2}{*}{$\begin{array}{l}\text { Phage } \\
\text { Type }\end{array}$} & \multirow[t]{2}{*}{ Resistogram Type } & \multirow[t]{2}{*}{$\begin{array}{l}\text { Dienes } \\
\text { Type }\end{array}$} \\
\hline & $\boldsymbol{Q}$ & $\boldsymbol{H}$ & & $I$ & 2 & 3 & 4 & 5 & 6 & 7 & 8 & 9 & 10 & 11 & 12 & Code & & & \\
\hline 747 & 3 & 1 & 5 & + & - & - & - & - & - & - & - & + & - & + & - & 4012 & $2 / 9$ & $\mathrm{~B}(\mathrm{C}) \mathrm{DEF}(\mathrm{G}) \mathrm{K}$ & D1 \\
\hline 347 & 3 & 2 & 1 & - & - & - & + & + & - & - & + & - & - & + & - & 0622 & $19 / 28$ & (A)BDE(F)GK & D2 \\
\hline 348 & 3 & 2 & 1 & - & - & - & + & + & - & - & + & - & - & + & - & 0622 & $19 / 28 /+$ & (A)BD(E)FGK & D2 \\
\hline 699 & 3 & 2 & 3 & - & - & - & - & - & + & - & - & - & - & - & + & 0101 & $19 / 28 /+$ & ABEFK & D3 \\
\hline 753 & 3 & 2 & 3 & - & + & - & - & - & + & - & - & - & - & - & - & 2100 & $\begin{array}{l}8 / 19 / 20 / 28 \\
31\end{array}$ & BCEF(G)K & D3 \\
\hline 759 & 3 & 2 & 3 & - & - & - & - & - & + & - & - & - & - & - & + & 0101 & $\begin{array}{l}8 / 19 / 20 / 28 \\
31\end{array}$ & $\operatorname{BCEF}(G) K$ & D3 \\
\hline 837 & 5 & 2 & 4 & - & - & - & + & + & - & - & - & - & - & - & + & 0601 & $\begin{array}{l}8 / 19 / 20 / 27 \\
28 / 29 / 31\end{array}$ & B(C)DFHK & D4 \\
\hline 836 & 5 & 3 & 6 & + & - & - & - & - & + & - & - & + & + & - & - & 4114 & $\begin{array}{l}8 / 19 / 20 / 27 \\
28 / 29 / 31\end{array}$ & B(D)EK & D5 \\
\hline 742 & 6 & 2 & 3 & - & - & - & + & + & - & - & - & - & - & - & - & 0600 & $\begin{array}{l}8 / 19 / 20 / 28 \\
31 /+\end{array}$ & BCF(G)K & D6 \\
\hline 750 & 10 & 2 & 3 & - & + & - & - & - & + & - & - & - & - & - & - & 2100 & $\begin{array}{l}8 / 19 / 20 / 28 \\
31\end{array}$ & (A)BCDEFG & D7 \\
\hline 775 & 10 & 3 & $\mathbf{N T}$ & - & + & - & - & - & + & - & + & - & - & - & - & 2120 & $\begin{array}{l}8 / 19 / 20 / 28 \\
31\end{array}$ & CD(E)FGK & D8 \\
\hline 700 & 10 & 4 & 8 & - & - & - & - & - & - & - & + & - & - & - & - & 0020 & $\begin{array}{l}8 / 19 / 20 / 28 \\
31\end{array}$ & BEK & D9 \\
\hline 713 & 11 & 1 & 5 & + & - & - & - & - & - & - & - & + & - & + & - & 4012 & NT & (A)BCDEFK & D10 \\
\hline 341 & 11 & 2 & 3 & + & - & - & - & - & - & - & - & + & - & + & - & 4012 & $19 / 28$ & BCDEGK & D11 \\
\hline 766 & 19 & 2 & 3 & - & - & - & - & - & + & - & - & - & - & - & + & 0101 & $\begin{array}{l}8 / 19 / 20 / 28 \\
31\end{array}$ & BCE(F)(G)K & D3 \\
\hline 850 & 19 & 2 & 1 & - & + & + & - & + & + & - & - & - & + & - & - & 3304 & $\begin{array}{l}8 / 19 / 20 / 27 \\
28 / 29 / 31\end{array}$ & $\mathbf{B C D}(\mathbf{G}) \mathbf{K}$ & D12 \\
\hline 708 & 20 & 1 & 13 & - & - & - & + & + & - & - & - & - & - & + & - & 0602 & NT & ABCDEF & D13 \\
\hline 608 & 23 & 1 & 2 & - & + & - & - & - & + & - & - & - & - & - & - & 2100 & $19 / 27 / 28 /+$ & BCDEFGK & D14 \\
\hline 706 & 23 & 1 & 2 & - & + & - & - & - & + & - & - & - & - & - & - & 2100 & $\begin{array}{l}8 / 19 / 20 / 27 \\
28\end{array}$ & $\mathrm{AC}(\mathrm{D}) \mathrm{HK}$ & D15 \\
\hline 859 & 23 & NT & 6 & - & - & - & - & - & + & - & - & + & - & - & + & 0111 & NT & ABCDEFGHK & D16 \\
\hline 762 & 24 & 3 & 1 & + & - & + & - & - & - & - & - & - & - & - & - & 5000 & $\begin{array}{l}8 / 19 / 20 / 28 \\
31\end{array}$ & ABCEF & D17 \\
\hline 687 & 26 & 1 & 1 & - & - & - & + & + & + & - & - & - & - & + & - & 0702 & $19 / 27 / 28$ & ABCDEF(G)K & D18 \\
\hline 568 & 26 & 1 & 1 & - & - & - & + & + & + & - & - & - & - & + & - & 0702 & $19 / 27 / 28$ & BF(G)K & D18 \\
\hline 352 & 26 & 2 & 1 & - & - & - & + & - & - & + & - & - & - & - & - & 0440 & $19 / 20 / 28$ & BCF(G)K & D19 \\
\hline 704 & 26 & NT & NT & - & - & - & - & - & + & - & - & + & - & - & + & 0111 & $8 / 19 / 20 / 28$ & ABDE & D20 \\
\hline 614 & 28 & 2 & 5 & - & - & - & + & + & + & - & - & - & - & + & - & 0702 & $9 /+$ & ABDEFK & D21 \\
\hline 760 & 28 & NT & 5 & - & - & - & + & + & + & - & - & - & - & + & - & 0702 & $8 / 19 / 20 / 28$ & BDEFK & D22 \\
\hline 705 & 28 & NT & 9 & + & - & + & - & - & - & - & - & + & - & - & - & 5010 & $2 / 9$ & ABCDEK & D23 \\
\hline 567 & 30 & 2 & 1 & - & + & + & - & + & + & - & - & - & - & - & - & 3300 & $26 \mathrm{~W}$ & AB(D)EFH & D24 \\
\hline 572 & 30 & 2 & 1 & - & + & + & - & + & + & - & - & - & - & - & - & 3300 & $26 W$ & (A)B(C)DEF & D24 \\
\hline 612 & 30 & 2 & 1 & - & + & + & - & + & + & - & - & - & - & - & - & 3300 & $26 W$ & $\mathrm{BCD}(\mathrm{E}) \mathrm{F}(\mathrm{G}) \mathrm{K}$ & D25 \\
\hline 854 & NT & 2 & 4 & - & - & - & + & - & + & - & - & - & - & - & - & 0500 & $\begin{array}{l}8 / 18 / 20 / 28 \\
31\end{array}$ & ABCDEFGHK & D26 \\
\hline 856 & $\mathbf{N T}$ & 2 & 4 & - & - & - & + & - & + & - & - & - & - & - & - & 0500 & $\begin{array}{l}8 / 19 / 20 / 28 \\
31 !+\end{array}$ & AB(C)EFGHK & D26 \\
\hline
\end{tabular}

Table VII Typing of 33 Proteus isolates by proteocine sensitivities and other methods

Al-Jumaili method. This compares with approximately $75 \%$ typability achieved by the CradockWatson method.

2 the larger number of strains demonstrated by the Al-Jumaili method as compared with the Cradock-Watson method. The 204 isolates typed by this method were shown to be divisible into 33 distinct proteocine sensitivity patterns whereas the Cradock-Watson method reveals only nine types, a miscellaneous group, and non-typable organisms. A total of 48 sensitivity patterns has been demonstrated elsewhere (Al-Jumaili, 1975) using 1000 Proteus isolates.

3 the greater specificity of the Al-Jumaili method. It can be seen that the Al-Jumaili system subdivides strains of Proteus which appear to be identical when typed by the Cradock-Watson system (table IV). Thus, where the Cradock-Watson type is frequent, for example, types 1 and 4, the Al-Jumaili system subdivides these types respectively into 10 and four sensitivity patterns. Thus a higher degree of discrimination between apparently similar isolates of Proteus is achieved using the Al-Jumaili method.

Also, the large number of untypable isolates are differentiated, in this instance, by the Al-Jumaili method into 18 separate strains on the basis of their sensitivity patterns, On the other hand, where the Cradock-Watson type is infrequent, for example, CW type 6, identical results are obtained with the Al-Jumaili method (table IV). This obviously 
indicates a degree of specificity for the Al-Jumaili system at least as good as that for the CradockWatson method. The remaining Cradock-Watson types $(2,3,5,9$, and miscellaneous and atypical) were also shown to be capable of subdivision into more specific groupings-four in type 2 , seven in type 3 , two in type 5 , three in type 9 , and 10 in the atypical and miscellaneous group. The Cradock-Watson non-typable group was found to consist of 18 different strains. Moreover, with the exception of those isolates falling into the Cradock Watson non-typable or miscellaneous groups, only five of the Al-Jumaili patterns $(4,13,20,16$, and 18) were subdivisible by the Cradock-Watson system. Al-Jumaili pattern 4 occurred in Cradock-Watson types 2, 3, and 5; pattern 13 occurred in CradockWatson types 1 and 2 ; pattern 16 occurred in Cradock-Watson types 1 and 3 ; and pattern 18 occurred in Cradock-Watson types 1 and 9. The remaining 28 patterns were not encountered in more than one Cradock-Watson type. Also, the most commonly occurring Al-Jumaili pattern (pattern 2) accounted for under $10 \%$ of the total isolates typed.

4 the greater simplicity of typing using liquid proteocine preparations. Although Dienes' typing and resistogram typing gave a larger number of recognizable strains than the Al-Jumaili system (using a small sample of 33 isolates) both methods are laborious and are not necessarily reproducible and consistent. The Al-Jumaili system, on the other hand, is easy to execute, and once the standardizing proteocine preparations have been obtained the typing may be performed on large numbers of Proteus isolates routinely with a minimum of effort and materials. Also results may be obtained within 18 hours of isolating a strain of Proteus.

As bacteriophage and the Cradock-Watson methods of typing Proteus appear to be unsatis- factory, it appears that the method described offers a simple and reproducible alternative to serology as the epidemiological tool of choice for the study of the spread of Proteus infections.

The results of the tests on nurse $A$ and the six infants from the Boston Hospital seem to support this. It was discovered that nurse A carried two different types of $P$. mirabilis, and it can be seen that the six children carried either one or the other of these same two types (table V). This concurs with the results obtained by the Cradock-Watson method on the same isolates.

In addition, four strains of gentamicin resistant Proteus obtained from the surgical ward of the Middlesex Hospital were found to have an epidemiological relationship as they all have a similar sensitivity pattern. This was also shown by the Cradock-Watson results. In addition they were all found to be $P$. vulgaris.

I should like to thank $\mathrm{Mr}$ G. A. Fenwick for his assistance in writing this paper, and $\mathrm{Mr} \mathrm{T}$. Pitt and $\mathrm{Dr}$ R. H. George who supplied the Proteus isolates.

References

Al-Jumaili, I. J. (1975). Bacteriocine typing of Proteus. clin. Path., 28, 784-787.

Burke, J. P., Adler, J. L., and Finland, M. (1970). Comparison of methods for typing Proteus mirabilis as applied in an epidemiological study of infections in a nursery for newborns. Antimicrob. Agents Chemother., 10, 328-331.

Cradock-Watson, J. E. (1965). The production of bacteriocines by Proteus species. Zbl. Bakt., I.Abt.Orig., 196, 385-388.

de Louvois, J. (1969). Serotyping and the Dienes reaction on Proteus mirabilis from hospital infections. J. clin. Path. 22, 263-268.

Kashbur, I. M., George, R. H., and Aycliffe, G. A. J. (1974). Resistotyping of Proteus mirabilis and a comparison with other methods of typing. J. clin. Path., 27, 572-577. 